\title{
Maritime Culture Degradation: History, Identity, and Social Practice of Seafaring in Banten
}

\author{
Amarulla Octavian, Marsetio, Bayu A. Yulianto, Hari Utomo, M. Adnan Madjid \\ and Susaningtyas Nefo Handayani Kertopati \\ Maritime Security Program, Faculty of Defense Management \\ Indonesia Defense University, Indonesia \\ *Corresponding author: amarulla.octavian@idu.ac.id
}

\begin{abstract}
Colonialism has been a preliminary thesis that can be addressed in the Indonesian maritime culture degradation. In order to restore the maritime culture, the current representation of degradation in the community level needs to be considered. This paper provides the historical process of Banten maritime culture degradation and the existing condition of degradation itself in the context of sea social practice on sociological perspective.
\end{abstract}

Keywords: Maritime; Culture; History; Representative; Social practice

\section{Introduction}

Degradation of maritime culture is one of the strategic issues that should be the Indonesian government's great concerns. This issue is very important because in 1994 the United Nations (UN) declared Indonesia as the world's largest archipelagic state. The rules and regulations in determining an archipelagic state derive from the decisions of UNCLOS III, which was announced by the UN in 1982. For countries that were determined as the world's archipelagic states - Indonesia, Philippines, Maldives and Seychelles, the articles within UNCLOS provide legality for their sovereignty at sea. UNCLOS strengthens the claim of a country that its seas and waters unite rather than divide. Based on the latest survey from the Indonesian Navy's Hydrography and Oceanography Service, Indonesia has 17,499 islands with coastal line as long as 81.000 kilometers. From the country's total area of 7.73 million square kilometers, only 1.93 million square kilometers are land and most of the country's area are covered by the seas and straits, which includes 2.8 million square kilometers of archipelagic waters, 0.3 million square kilometers of territorial seas, and 2.7 million square kilometers of Exclusive Economic Zone [1,2].

Indonesia's status as an archipelagic state holds important consequences, both upon the identity of its people and the nation's character [3]. Based on Giddens [4] understood society as a social construct that continues to experience structuration within, culture in the context of this research refers to the dynamic and continues social process between an individual and his or her society in producing all kinds of social realities that are related with how a society survives, develops, or, in contrast, extinct. Under such conception, conflicts, integration, structuration, identity strengthening as well as numerous kinds of social process within a society involving various social institutions including the cultural products that came from these processes, could be understood as culture. On a more concrete level, national development should be viewed as an integral part of a society's cultural development.

Although the sea dominates Indonesia's nature and geography, the fact is such reality does not go hand in hand with its cultural development. Currently, Indonesian culture has distant itself far from its maritime and seafaring culture. It tends to direct on a single cultural pattern that is land-oriented, a culture marked by a number of characteristics, 
including minimum knowledge of knowledge about the sea compared to land, the domination of land-oriented economy rather than maritime-oriented, a set of sea mythology system that pushes people away from the sea and view it as a divider and not a medium that unites. A clear implication of this land-oriented culture is the seas and oceans are seen as the society's back door in the interactions within the country and with others. It is very contrast to Indonesia's own history which includes an era of a grand maritime civilization. This era did not only occur in Indonesia, but covered almost all of Southeast Asia in the $15^{\text {th }}$ until $17^{\text {th }}$ century [5].

In the context of Indonesia, Dahana [6,7,8,9] through a number of his articles in Kompas Newspaper, expressed his restlessness on how the society's daily life does not reflect maritime culture. It is as if Indonesia's maritime culture that once reflected the people's inclusiveness upon changes, egalitarian ways and openness to new ideas disappeared without a trace. In regards to the understanding that a maritime society practices egalitarian attitude, this notion is strengthen by a verse from an ancient Javanese scripture, Kakawin Sumanasantaka. In one of its chapters, the manuscript, written by Mpu Monaguna in the $13^{\text {th }}$ century explained the aristocrats' point of view on the social behavior of a maritime society. Rhyme 50 verse 11 describes a princess reluctant to visit the coastal area since she believed the people living in the area do not value social differences among humans [10]. This verse can be seen as a sociohistorical fact that a maritime society that lives along the coastal area has a significantly different point of view compared to societies living in the mountains in terms of social equality.

On the other hand, Indonesia is not the only country that has issues in terms of lack of maritime culture. Hans Dieter Evans wrote in article about Malaysia, which is also a member of ASEAN, where he pointed out a question on the country's maritime culture:

"... but the question could, indeed, be extended to the more general problem, when and why Malaysia's majority ethnic group, the Malays' a people with Polynesian connections and a long history of seafaring across oceans, have turned away from the sea, looking inward to land areas rather than maritime "space between the islands"' the Nusantara, and beyond." [11].

This question rose at a time when it was apparent that many of Malaysia's development policies were land-oriented rather than maritime-oriented. Historical explanations on maritime culture degradation are considered insufficient to provide a complete understanding on the issues complexity in today's setting. Hence, both authors conducted a research to provide a manifestation of representation of the degradation in a smaller and more focused scope. The study was conducted to see whether the historical process explained before continues until today in the scale of social action or practice in a society. The research was supervised by the Indonesian Defense University's (IDU) Research and Community Service Center. This empirical research is also one of the bases for the teachings of Maritime Sociology in IDU. The research includes a historical study on the downfall of Banten maritime culture in the past, observation, and interviews with people living along the Banten coastline, especially in Ujung Kulon. This empirical study on data and information is done to look for the connection between historical explanation, macro by nature, and social practices that are micro and meso. Banten was chosen as an area for this case study because of its history as one of Nusantara's greatest maritime empires. Similar to other kingdoms and empires in Nusantara, after it was defeated by the Dutch, the orientation of the ruler and the people changed. No longer do they look to the sea; they transformed into agricultural societies with orientation to the land and, hence, forgotten the sea as their front yard. This empirical research was done in three coastal villages in Banten Province, in Pandeglang District, Sumur Sub-District. These three villages are Taman Jaya, Cigorondong, and Ujung Jaya, and each reflected different relations between a society and the sea.

This article is written to answer several main issues, which are as follow. As a country 
with a long coastal line, why is maritime culture not reflected in Indonesia's society? Why is Indonesia closer to agrarian culture when its lands are only a small fracture compared to its seas? Despite the existence of early assumptions on the role of colonialism in deconstructing Indonesia's maritime culture, how far is the maritime culture degradation happening in today's society? Contextualization of these basic questions is a reflection of hope that by understanding the root cause of Indonesia's maritime culture degradation, we could have sufficient knowledge base to develop a contextual and strategic system for maritime society development.

The rest of this paper is organized as follow: Section 2 describes the proposed theoretical framework. Section 3 describes the main results i.e. seafaring as a social practice: history, identity, and knowledge. Finally, the section 4 concludes this work.

\section{Theoretical Framework}

\subsection{Maritime Culture}

In the elisionist perspective driven by Giddens [12] and Bourdieu [13], non-stop reciprocal relations between individual and structure become the basis for a society's social realities. They believed that the rigid separation of social facts and symbolic interactionism perspectives could not explain existing problems in the age of modernization up until today. Based on both perspectives, culture can be understood as a single social arena within a social order where redefinition and restructuration occur constantly. It is a society that gives birth to culture. Therefore, in order to understand what maritime culture is, we should first understand the definition of maritime society. According to Janizewski as cited by Bartlomiejski [14] maritime society represents a local society with a unique social type. Its definition is broader than just a group or society of fishermen. Not only does its members live along the coastline and catch fish at sea, but they also have norms and social obligations that come from their long relations with the sea. Their identity as a maritime society is attained from a social process of experience and understanding the society's relations with the sea. Meanwhile, Cameron [15] explained the sociological realities on the diversity of socio-cultural orientations of different societies toward the sea, although each of these groups of people share the same physical opportunities and economic needs. He wrote that not all societies located near the sea attain the same strong connection with the ocean, including in how they determine division of work among themselves.

Lapian [16] explained how maritime culture is not a form of domination of those living along the coast against those living further inward. Nusantara maritime culture was strengthened through the process of goods exchange between the people of the coastal areas and the ones living inland. Although in terms of trade among islands required the skills to sail the sea, both ship-building and navigation skills to achieve the intended destination. In the end, if we take Giddens [15] explanation to explain social practices in a society, seafaring could be seen as the confluence of a slightly loose structural constraint with the awareness of an individual as he interacts with the structure that surrounds him. In short, sociologically, seafaring is about fulfilling economic demands as well as a way of life. Seafaring or maritime culture could then be understood as a social arena where interactions happen among i) interpretative scheme involving knowledge about the sea; ii) social rules covering social sanctions and institutions within a maritime society; and iii) facilities that can be categorized as sources that are the modalities of an individual that will go seafaring (see Figure 1). 


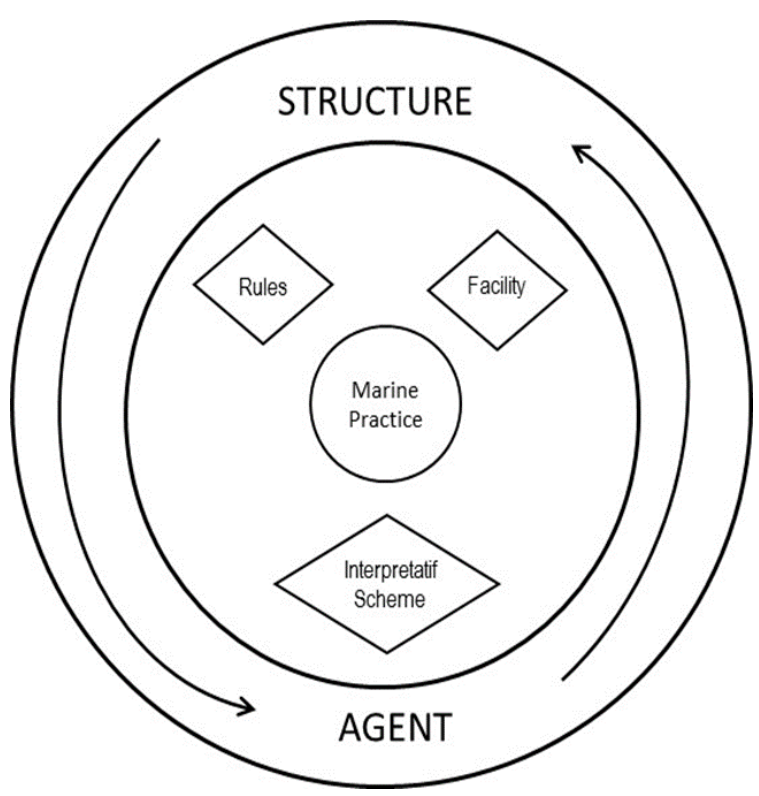

Figure 1. Seafaring as a Social Practice

\subsection{Issues of Identity}

An anthropologist from Bombay University who attended the International Conference on Man and The Sea in Princeton in the summer of 1965 raised a challenging statement on maritime culture:

"Perhaps as social scientists, we must admit that cultivation of the seas can only flow from cultivation of the kinds of men and women who make the seas their own. But what do we then have to say about how to cultivate such people while there is time?"

Before he expressed this statement, he first explained in detail the condition in his own country. India, according to him, is a country with a large number of population and serious food issues. India also has a long coastal line as well as a number of people that uses traditional methods to catch fish at sea. Nevertheless, the number of fishermen in India could not outnumber the country's farmers. He then compared India with the United Kingdom, France, the United States and Russia. He believed that India has the same fate as Egypt and Somalia, where their people rarely venture to the seas [15]. It is very much relevant that we study further what Cameron in [15] mean by the meaning of "the kinds of men and women who makes the seas their own". Here, the issues of social groups or even an identity group with seafaring knowledge and skills are the core of seafaring practice dissemination. The question we should ponder on then would be how does this process occur? Sociologically, what kind of relation pattern that would rise during the reproduction of this action? The most critical question is whether the Bombay University anthropologist statement is true or false?

On identity issues and intragroup relations of a fishermen society, Ebbin [17] compared two fishermen groups, the Puget Sound fishermen in Washington and Kuskokwim River group in the western part of Alaska. The research showed the connection between identity and fishermen social conflict. Changes in the anatomy of conflict significantly influenced the conception of collective identity. The core of Ebbin's explanation pointed out how an identity that is manifested as a collective feeling and shared ownership lies in a very dynamic social situation [17]. Limits of a group that are the basis of differentiating groups could change at any given time, both because of social and political structures that surround them and the dynamics of group members, who also have a broad relation with structure, as well as individuals beyond the identity groups. 
In the beginning of The Power of Identity, Castells [18] wrote that identity is the source of an individual's meaning and experience. Hence, identity is closely related knowledge that could contribute to the construction of an individual's meaning and understanding of himself. Knowledge referred here means the ability to identify oneself, especially self-knowledge and the others. Castells [18] also quoted Calhoun:

“...self-knowledge--always a construction no matter how much it feels like a discovery--is never altogether separable from claims to be known in specific ways by others.

Castells [18] continued his conception on an identity that could start from a dominant institution that it could become an identity when the social actors internalize it and develop their meaning basis from the internalization process. Meanwhile Giddens [15] noted that identity is the source of self-interpretation for social actors as well as a construction constructed by these actors through individuation process. Although there are differences on how Castells [18] and Giddens in [15] understand identity, it is clear that their explanations confirm that identity construction leans toward a continuous process. This process also signals that identity is a construct that continues to move by redefining itself when facing the others.

\section{Seafaring as a Social Practice: History, Identity, and Knowledge}

Maritime culture degradation studied through this research is visible in the dynamics of seafaring social dynamics in the society level. To explain such dynamics, three key issues will be discussed. First, historical dimension that brought about the degradation. Second, representation of the degradation in current time. Lastly, the involvement of identity in the context of seafaring social practice. Historical dimension will show how colonialism played a substantial role in maritime culture degradation in Banten. The degradation in the current context is represented by the constriction of the meaning of seafaring compared to its meaning in the past. At this point, identity groups have a strong role in preserving the knowledge and values of seafaring, causing such practice to remain until today in relatively limited scales.

\subsection{A Short History of Maritime Glory Degradation in Banten}

In the age of maritime trade, both during the times of Srivijaya and during the era of Islam Kingdoms of Nusantara, cultural development was supported by interisland trade system that capitalized on the existence of port cities along the coastline, from the eastern and western coastlines of Sumatera to the norther coastal areas of Java. Maritime trade was also supported by large port cities of the East such as Makassar, Ambon, Ternate and Tidore [19]. Vibrant port cities of Nusantara is an unavoidable consequence of the sea-borne trade route connecting the East and the West.

Wolters [20] notes confirm that Srivijaya's rule and domination along the Strait of Malacca provided enormous service in integrating the trade routes of the East and the West. He wrote that shipping routes from the Bay of Bengal to Nusantara and from China to Nusantara were once not connected to one another. Each route developed during different eras with centuries in between. Reid [5] explained that the golden ages of Nusantara port cities, which occurred during the $15^{\text {th }}$ until the $17^{\text {th }}$ century, are an integral part of global trade development. Long before colonialism arrived in the region, the connection among people in the region was dominated by maritime relations. In East and West Asia, two trade routes were well-known, the land route (the Silk Road) from China, Turkestan (Central Asia), India, until the Mediterranean Sea until Arabia, and the sea route starting from the South China Sea, the Strait of Malacca, Kolkata, the Gulf of Persia, the Mediterranean Sea until Egypt and Europe. These routes are very different to Nusantara since the area was totally dominated by sea routes since it was more challenging to go through land than 
through the sea. Reid [5] underlined that land trade with caravans had its limitations in reaching remote areas as land infrastructure were not sufficient during that time. The lands of Southeast Asia, according to Reid [5], were perilous to venture out with dense forests, high rainfall causing floods during rainy seasons and dangerous rivers. Sea-borne trade created the era of trade in this region and pushed caravan trade to also develop further.

Port cities were not only centers of trade but also arena for groups to interact with one another equally. In this context, Reid [5] agrees with Tome Pires whom understood social interaction process in port cities often developed without involving class issues, but more on social groups, including ethnicity, religion, tribe as well as other forms of identities. The involvement of women in the maritime trae system also represented the egalitarianism principles of the region's maritime society. Lapian's historical studies [16] pointed out the strong relation between shipping and trade with inter-tribal social integration in Indonesia. According to Lapian [16], the sea provided room for intense interaction among small kingdoms scattered around Indonesia's islands. Economy, cultural and sometimes political relations are connected or were connected by larger units. Interisland communications and connection were possible thanks to a better maritime connection, advanced ship-building technology, navigation skills and a large enterprising spirit developed by the inhabitants of the islands.

\subsection{Banten in the Past}

Banten Port was one of the biggest ports in Nusantara thanks to its trade on pepper and nutmeg. The vibrant trade of crops promoted dynamic interaction between the coastal and inland areas. This was also supported by an external factor, the fall of Malaka Sultanate into the hands of Portugal. According to Lombard [22], one of the areas in Nusantara considered as the medium of cultural meeting among various groups of society is the Sunda Strait during the reign of Banten Kingdom. A French sailor by the name of Claude de Forbin in his travel notes written in 1686, published in Dorleans [23] detailed the vast and cosmopolitan Banten hi visited in 1670. Reid [5] stated during the period of 1400-1650, Southeast Asia played an important role in global trade system thanks to the regions crops and produce, such as clove, nutmeg, pepper, camphor, sandalwood, and varnish. This region Reid calls "the lands below the winds had its own centers of trade, including Pegu, Ayuthya, Pnompenh, Hoi An (Faifo), Melaka, Patani, Brunei, Pasai, Aceh, Banten, Jepara, Gresik, and Makassar [5]. These cities were quite influential until the colonials entered the regiona and gained control over a number of important areas, which then replaced the role of these cities. These colonials were Portugal in Malaka, the Dutch in Batavia, and Spain in Manila. In the $16^{\text {th }}$ century, as told by Reid [5], Banten became the only place for pepper plantation in Java Island with production capacity of 2,000 tons annually [5]. The interaction between Banten's coastal and inland areas was a continuous relation, providing benefit and openness to each other. Resources from the inland areas created Banten's function as a trade city [21].

Banten Sultanate was one of the many sultanates that gained benefits after Majapahit golden ages ended. The fall of Majapahit gave room for Islam kingdoms such as Demak, Jepara and Banten to develop, and historians consider it as a transition era, from Southeast Asia's classical era to its early modern time [24]. Majapahit's demise was considered due to the change of policy orientation from the sea to land. When Majapahit reached its glory and prosperity from trade in the Hava Sea, its people and noblemen built temples and conducted sacred rituals in inland areas [24]. Different to Aceh with its religious spirit in facing Portugal in Sumatera and Malacca Strait, Banten developed trade relations with the colonial. Banten flourished dramatically when Portugal controlled Malaka in 1511. Muslim traders from all places established a new shipping route through Sumatera's western coastline from Malacca Strait and continued sailing through the coastlines of Java Island. Banten and Portugal's harmonious relation did not stop on trade when the former requested assistance as it faced Demak under Pati Unus. In trade of its military assistance, Portugal 
requested the rights to build a fort in Banten [25]. Banten Sultanate was established by Sultan Hasanuddin in 1568. Its territory also covered all of western Java (before was Sunda Kingdom). Banten became wealthy as the center of pepper trade [24]. As a product of the trade era, Reid [5] categorized Banten as a contradiction in that era. Built facing the sea to attain profit from shipping, the city grew rapidly as a cosmopolitan metropolis where all merchants could trade freely along with unchecked groups roaming the city and a mix of confusing trenches, streets and markets. Port cities such as Banten during this era were not parasites extorting profit from inland areas. On the contrary, these cities were able to attain wealth from trade, in which local produce from inland areas moved swiftly in open markets of the city [5].

\subsection{Degradation of Banten's Maritime Culture}

The degradation of Banten's sea port in the past is closely related to the Dutch's role in 1605 , where the colonial considered the possibility of finding a new port to replace Banten $[21,26]$. Banten's degradation did not happen alone, especially since it was a sultanate with strong orientation on maritime economics and politics. During the same time, there was a degradation process among other kingdoms and sultanate in Nusantara, including some of Southeast Asia's largest maritime empires. According to Reid [5], Southeast Asia's maritime trade degradation occurred around the $16^{\text {th }}$ until the $17^{\text {th }}$ century, due to Europe's financial crisis (external factor) and internal fraction within kingdoms as well as economic and political contradiction between the power of the king or sultan and the new emerging middle class, a new class that came to be as an implication of trade activities in the region. Reid [5], proposed eight large kingdoms or sultanate that according to other historians represented the condition of that era. Nevertheless, Banten, which was under the reign of Sultan Abdulahfatah Ageng (1651-1682) received a special note from Reid [5] since the sultan was highly praised and respected by many in Netherlands. Lapian [16] confirmed the role of the colonials in the fall of Banten as he wrote that the Ducth failed to bribe Banten's syahbandar or the ruler of the port to take its side in 1619 when VOC started to control Jayakarta. The Dutch then pushed all traders to instead go to Jayakarta Port. Eight years later, Banten's trade fell completely in Dutch's hands.

The VOC monopolized the pepper and spice trade in Banten by creating massive blockades upon trade activities in all ports in Nusantara. Rulers of Banten, Aceh, Bugis and Makassar then proposed farmers to plant crops rather than peppers and spices. Pepper supply decreased drastically and people in these kingdoms fell into poverty due to lack of trade activities [5]. Thus, began the dark era of Nusantara's maritime trade.

\subsection{Representation of Maritim Culture Degradation}

If in the past seafaring had a significantly broad meaning and practice, today what we have is a drastic reduction in the meaning of this social practice. The macro-historical explanation in the previous part provided an illustration that seafaring was a social practice based on a dynamic relational tie between society and the sea [16]. It manifestation varies from catching fish for basic needs, sailing to other places to visit relatives, to find work, spread religion, until the use of ships for trade and even means to conquer and to conduct warfare. These were all practiced by people in that era through sea routes by using boats or ships of many sizes. How about today's practice?

The fact is the situation has changed. The people along the coastline of Ujung Kulon where the research was conducted also experienced such changes. Remnants of the broad understanding and meaning of seafaring as a social practice could be found in limited number and information. It is, however, it is certain that in the current degradation process the role of the state and the government is fairly pivotal in pushing the issue forward.

If the past considered seafaring to have a broad meaning, today's society development have reduced its meaning. Seafaring nowadays only connotes catching fish at sea or taking 
tourists to visit small islands along the coast of Ujung Kulon. Motor boats once had multiple functions, from finding fish, delivering crops or seafood to be sold in large cities like Labuan or Cilegon, to bringing home basic necessities and other goods that the area did not produce. Goods distribution by sea motors or motor boats were last practiced in mid 1980s. Afterwards, they were used only to catch fish and take tourists to visit islands.

The social practice of seafaring, which in the past covered many interests, slowly has lost its deeper meanings and functions due to a number of factors. First, the emergence of alternative land route. Although inadequate, but it provides a different route for the people in the area. Second, the use of motor boats is considered inefficient with unpredictable weather condition that forces moto boat users to move near the coastline a number of times during their trip from Ujung Kulon to Labuan or Panimbang. Third, the cost of loading and unloading goods using moto boats is quite substantial because the process is conducted several times, from loading goods to the vessel, unloading them from the boat, taking the goods to the warehouse using land transportation, until finally loading the goods in the warehouse. Unfortunately warehouses in Panimbang and Labuan are not located near ports or the coastline, which would allow easy access for the motor boats. Most warehouses are located around inland areas and so both buyer and seller must pay a hefty price for loading and unloading goods when using motor boats as medium of transportation. There are the reasons why motor boats are considered costly in terms of transporting goods in the area. Lately it is harder for motor boat users to enter ports, both in Panimbang and Labuan due to sedimentation. Often motor boat users must wait for a day for high tide so their vessels could enter. This latest problem has significantly interfere with the effectiveness of their goods transportation.

\subsubsection{Here Comes Cars and Trucks}

It was around 1985 when H. Hasan decided to buy a pickup car to take his catch of the day to a warehouse in Labuan. He believed it would be more effective since transporting his catch by motor boat has become more inefficient in terms of cost and time. His profit was then used to buy a car to jumpstart his freight business for the locals. Even though the distance was short since road infrastructure was still limited, many locals followed his path. The ironic part of the story, his new car was sent by the dealer from Labuan to his doorstep by motor boat.

This story illustrates how a social intervention process in a coastal village through the introduction of a new technology, a car, slowly but sure created a new knowledge that did not exist before in the area. The existence of cars as land transportation provided proof for the locals there is a better transport vehicle than motor boats. Although in some cases the use of cars is yet optimum because of lack of road infrastructure. Still, a new awareness starts to blossom in their minds that having better roads is essential so that cars could drive through. The future of their interaction with the outside world lies on land transportation technology since the use of motor boats have failed to advance them better than other societies. In this context, cars and trucks are just one small manifestation of how knowledge could come, develop and finally dominate.

Nowadays, bad road condition does not hinder new cars and motorcycles from passing through. The same does not apply at sea. We still encounter many fishermen using motor boats or ships. Nevertheless, the machines they are using remain the same with the ones used decades ago. It is not only a matter of technology; infrastructure for ships to berth remains unavailable. From some of the locatiosn where fishermen berth along the coast of Ujung Kulon, such as Muara Cibanua, Muara Cikawung, Legon Guru, Tanjung Lame and Katapang, only the former looks like a proper port. The rest are merely estuaries developed by the locals. Sociologically, cars and trucks are what Giddens [15] categorized as a facility or modality that determines how a change in a society works. In turn the facility would give rise to an interpretation of a progress. At this point, social structure in the perspective of elisionist push forward a process of maritime-oriented cultural marginalization by a 
land-oriented culture in the societies of Ujung Kulon.

\subsubsection{Fishermen Shipping Industry}

The advancement of land transportation technology, such as cars, motorcycles and trucks, are in very much contrast with the condition of fishermen shipping industry, which seems to remain the same in the past few decades. Though land transportation industry is nowhere located around the location, the consumption of the products is massive. This is evident in the number of locals owning mostly motorcycles and some with cars. Some own minibuses and utilize them for public transportation from the villages in the coastline to cities of Sumur, Labuan, Rangkasbitung and Serang. In short, land transportation development is rapid. This is unlike sea transportation, which has yet to experience any meaningful and significant development in its form, model, material and technology. The main issue of this comparison is not the scale of industry, but more on how knowledge as the basis of a civilization process of a society development experiences stagnation. In other words, the inability to develop oneself in order to support the social practice of seafaring. Though on a micro scale, the knowledge of traditional ship building and maintenance remains. The existence of a maritime service industry operated by a number of individuals sociologically points out how maritime culture is marginalized.

Jarman and Armin, two ship builders represent such a reality. Both are handymen for fixing old fishermen vessels, also able to build new ones from wood. Their knowledge on the process of boat or ship building is based on their experience along with catching fish at sea; they complete this very local capacity of knowledge and maintenance practice as well as ship building. They have never received any support or assistance from the government of the private sector in their service. Their ability to remain as traditional ship builder in the area lies on their hard work and the trust from ship owners who came to have their ships fixed. Under the pressure of rapid development of land transportation, small-scaled fishermen ship building industry survives and able to answer technical shipping problems faced by fishermen. Sociologically, these ship builders developed their knowledge through non-formal education system. During the process of ship repairing and building, the assistance of nature and environment is very important due to the limitations of means and infrastructure. Besides inadequate means and infrastructure for ship building and repairing, the ship building system's most advanced innovation is on energy. In the past, tools were operated manually, but now electrical ones are available, such as electric drill and saw. Beyond these tools are manual. Much part of the ship building process in this area utilizes the natural conditions of the area's surrounding to help the process of not only building but also repairing ships. For example. Building a ship in the midst of lush trees is very important so that the trees' huge trunks could double as lifting equipment. This process is important during hull repair process. Ropes are used to tow the ship up above the ground.

Sociologically, the survivability of local ship building and repairing industry in this area is possible since the knowledge and practices are a part of the society's social structure. Ship owners remain to rely on ship builders like Jarman and Armin to repair their old ships and make them new ones for seafaring activities. In this context, a misleading intervention could push such knowledge to vanish along with the current maritime culture degradation.

\subsection{Identity Paradox}

One trend evident among villages along the Ujung Kulon coast - where this study was conducted - is the domination of agriculture, even though these villages are located close to the sea. Such close natural distance could not reduce the distance between social realities and culture. Hamid [24] noted the importance of agricultural support to port areas as a single economic system supporting maritime trade. He wrote that well-established and busy ports requires significant logistical support, such as water and rice, for sailors going for weeks and months of seafaring. Hence, many societies in the coastal areas also develop 
agricultural produce. In the historical context, such activities were done to support a larger economic system, which is a maritime economy system.

In other words, agricultural production in the past inherited a broader orientation since it was not only for the sake of domestic consumption of a particular society, but also to support political and economy activity at sea. Agricultural practices did not focus on social activities on land only, but to further support activities onboard ships, the medium for intergroup interaction during that time. Therefore, we should understand that agricultural activities along the coastal areas that are not sea-oriented did not rise abruptly nor they are an antithesis of economic activities at sea; they are not activities against seafaring activities. If in the end agricultural becomes more dominant the seafaring in the coastal areas, this phenomenon actually reflects a paradox reality where the coastal area has two distinctive faces at the same time, land and sea.

\subsubsection{Fisherman Farmer-Farmer Fisherman}

If a society's natural distance to the sea could be defeated by social distance (perhaps even cultural distance), we should ask the question on how could it happen in the context of the people along the coastal area of Ujung Kulon? As we refer to Giddens in [15] that an individual is able to negotiate with and redefine against the structural constraint surrounding him, we should wonder how such negotiation occurred. What choice of structural alternatives that the people could develop in order to relax the structural keys restraining them. Concretely, what is the manifestation of this continuous negotiation?

When asked on their occupation, most locals in Ujung Kulom would answer farmer-fishermen or fishermen-farmer. Their position under the farming or fishery production structure quite varies and still follows the old relation pattern between owner of modality that controls a great number of asset, while the poor own limited number of production tools, both for farming as well as for fishing. For the people of coastal area of Ujung Kulon, farming or fishing is not a matter of fulfilling basic needs of life; both have a more specific and contradictive meanings. For most people, farming is a value of stability, while fishing inherits bigger risks although the profit is also significant.

Different social-economy contexts share this point of view. The lower class considers seafaring as a more promising occupation. The uncertainty factor, however, is considered high since catch rate varies from big catches to catching nothing at all. This is evident during the monsoon season when the waves are too big to sail and is the toughest season for fishermen because of zero income. Fishing tools experience depreciation due to constant use by fishermen. During high tide, some parts would go missing, leaving the equipment broken and could no longer be used anymore. Seafaring is often seen as a less stable way of livelihood though it promises a large sum of profit. On the other hand, informants in our research explained the other reason why farming is considered more stable compared to fishing; because the cost for a single season of farming - from planting to reaping the fruits of labor as well as profit - is clear and evident. Farming may not provide immediate return of profit like fishing, but its investment, the land, is believed to continue its value from time to time. Hence, most people consider farming provides a sense of stability and harmony.

The strengths and weaknesses of the two different means of utilizing natural resources influence why most of the people in Ujung Kulon feel comfortable being in between these two occupations. Rice farming provides stability as it ensures the availability of rice at home after a certain period of time. Fishing at sea, on the other hand, provides the possibility of making a huge profit. These two ideals apply universally, even for modern societies living in cities. They also want big income and the sense of security of a stable life, especially in the long term. When each livelihood orientation could not fulfil the two ideals directly, accommodating both becomes the chosen way out; becoming fishermen as well as a farmer and a farmer as well as a fisherman. 


\subsubsection{Bugis-Sunda: Sharing Profession and Identity}

The discussion of the sea and seafaring in this area should always look at the role of Bugis ethnicity since the 1970s. Until today there is one small village of Kampung Cibanua in Desa Taman Jaya that is called Bugis Village since most of the people living there are of Bugis ethnicity. There houses still have the characteristics of Bugis traditional architecture with tall poles. But in terms of language, it is a mixed of Sundanese language with a strong Bugis accent. Today, many of Sundanese people living in the area are fishermen and some are even owners of bosses, although the collective memories of Sundanese as farmers remain. This understanding often rises during conversation with many parties in the area, including Sundanese and Bugis. On one hand, although Bugis people admit their closeness with the sea and the profession of fishermen, most have left the profession for farming. Here, the profession of farming and fishing that once were an integral part of their ethnical identities has slowly degraded and a process of switch happened without conflict or dispute.

Sociologically, the ongoing social process converge the previously rigid lines of boundaries into blur. The social process within the people of Ujung Kulon's coastal area has become a quite dynamic arena for the convergence of several cultures, even though it may not change existing social structure or stratification. It also allows knowledge and identity-based experience exchange. Hence, culture becomes the arena for related parties to share identities.

Identity is important in terms of dissemination of seafaring knowledge and practice. Bugis fishermen contributed heavily to the introduction of the knowledge of sea to Sundanese people living in Ujung Kulon. Some Sundanese fishermen admit they just learned about high-valued seafood types from Bugis fishermen. One of them is Jerbung shrimp, which previously was not considered as a valuable seafood commodity, and even became the favorite of seafood catch, particularly in certain seasons. This kind of knowledge could develop further and may be understood as the basis of a social action because it was socialized by Bugis fishermen. In today's practice, however, its relevance has degraded.

The position of identity in seafaring social practice becomes irrelevant when seafaring is internalized well as a practice of more than just one group, including Sundanese ethnicity. At one point, it is possible for a particular social group to dominate the collective understating of seafaring practices, but when this knowledge and practice are internalized into individuals outside that group, they developed themselves while at the same time adopting characters different to the ones prior to the internalization process. Furthermore, the social position of individuals of a society has more leverage in determining compared to identity. The ability to accumulate capital, develop relations outside the group, increasing knowledge capacity are important elements that blur the existing identity-based limits. Nevertheless, the charm of identity remains as it is integrated as one of society's collective knowledge. In other words, identity as part of the social construction has found its context when knowledge was introduced as well as when knowledge develops in cognitive structure of individuals. The knowledge of the sea becomes important in a maritime identity project.

\subsubsection{Maritime Knowledge and Identity}

The issue of identity is important in terms of seafaring social practice dissemination, although not in a static social condition, when knowledge of the sea in a particular area is still new. When such practice becomes well-known, it goes through identity partitions, which were the basis of seafaring awareness. Giddens [15] explained identity as a social construction that dwells in a dynamic situation. Basic changes of a knowledge system in which an identity-based collective feeling is inherited eventually influence the people's interpretations of the sea. Though sociologically seafaring knowledge was able to break though the partitions of identity, no one could deny Castells' opinion [18] that identity is 
the source of understanding an individual's social. Hence, the debate no longer dwells on the role of identity in the social practice of seafaring. It should see how far identity could push the distribution seafaring knowledge and skills. We should go back to the argument from the Bombay University anthropologist quoted by Cameron [15]. He underlined how the dissemination of seafaring as a social practice is only possible by those who live and depend directly upon the sea. Is that true?

In order to answer the first question - how identity could promote the dissemination of seafaring as a social practice - we should look back at individual as well as collective initiatives of the people of Ujung Kulon coastal area, especially initiatives related to the decisions of people to become fishermen. Our study found three important things when researching on the position of identity in the social practice of seafaring.

a. First issue is the structure of fish production in the area that is closely related to the arrival of Bugis fishermen, currently living in Cibanua. Their position in the fishing commerce is central, if not dominant. One could see Kampung Bugis as the center of all social practices related to the sea, including fishing, fish preservation, ship building and repairing, sea festivity traditions, which are not found in other villages. If there are such practices in other villages, it would not cover all of these aspects.

b. Second, the central position of Bugis people in terms of seafaring knowledge and practice is well socialized. For most people in Ujung Kulon coastal areas, both farmers and fishermen, the sea equals the Bugis people. No one in the area would deny the totality of Bugis people in terms of living from the sea. It has become a knowledge buried deep within the subconscious of the coastal people in Ujung Kulon. Although today there are more successful Sundanese fishermen, they realize they could never rival the totality of the Bugis people. This understanding have pushed many to work as the crew of ships belonging to Bugis people, so not only do they work but they could also gain profound knowledge on seafaring. The accumulation of such knowledge finally pushed these workers to become fishermen themselves. In this context, the position of knowledge is very crucial since in order to start any seafaring activity or to become a fisherman, knowledge about the sea holds a very important role.

c. The third way is, which is common in an open society system, is through marriage. When the social condition of the village tends to be open, it allows marriages between different identity groups, and such practice also includes the marriages between people from Sunda and Bugis along the coastal area of Ujung Kulon. It is often that such marriage between the two ethnicities started the initiative, particularly from Sunda ethnicity, to start a business or find work related to seafaring. In some cases such a marriage allow each ethnicity to expand its business or to try new areas. From these three identified issue, we could then respond to the anthropologist's comments quoted by Cameron [15] in his article "Ahoy, Marine Sociology". Indeed, identity group plays an important role in the social practices of seafaring during the initial stage, which is when semi-professional practice of seafaring is not practiced by the majority of the general public. On the other hand, through the same process, the social practice of seafaring could break through beyond existing boundaries of identity until it finds a situation where identity no longer plays a strong role like it did before. Cameron's [15] argumentation should include the word "context" that allows identity to have more possibilities of existence. Context provide a different meaning to identity. The initial context gives pressure to the power of identity group to disseminate the social practice of seafaring. On the contrary, the current context shows how identity could no longer influence this social practice dominantly.

\subsection{The Sociological Dimension of Seafaring as a Social Practice}

The case of the coastal area of Ujung Kulon, the social practice of seafaring is a process 
involving schemes of effective knowledge of the sea and seafaring; a variety of economic condition of the people; the natural closeness of the people and the sea; and identity groups that historically are close to the sea in terms of social and cultural. These factors became structural constraints and influence the consciousness of individuals about the sea and seafaring. In a dynamic interaction process, such an awareness inherits a reflective ability in defining the social process that occurs around individuals. This interaction process then created the social practices of seafaring that are different to one group to another qualitatively. This diagram below provides an understanding of this social process (see Figure 2).

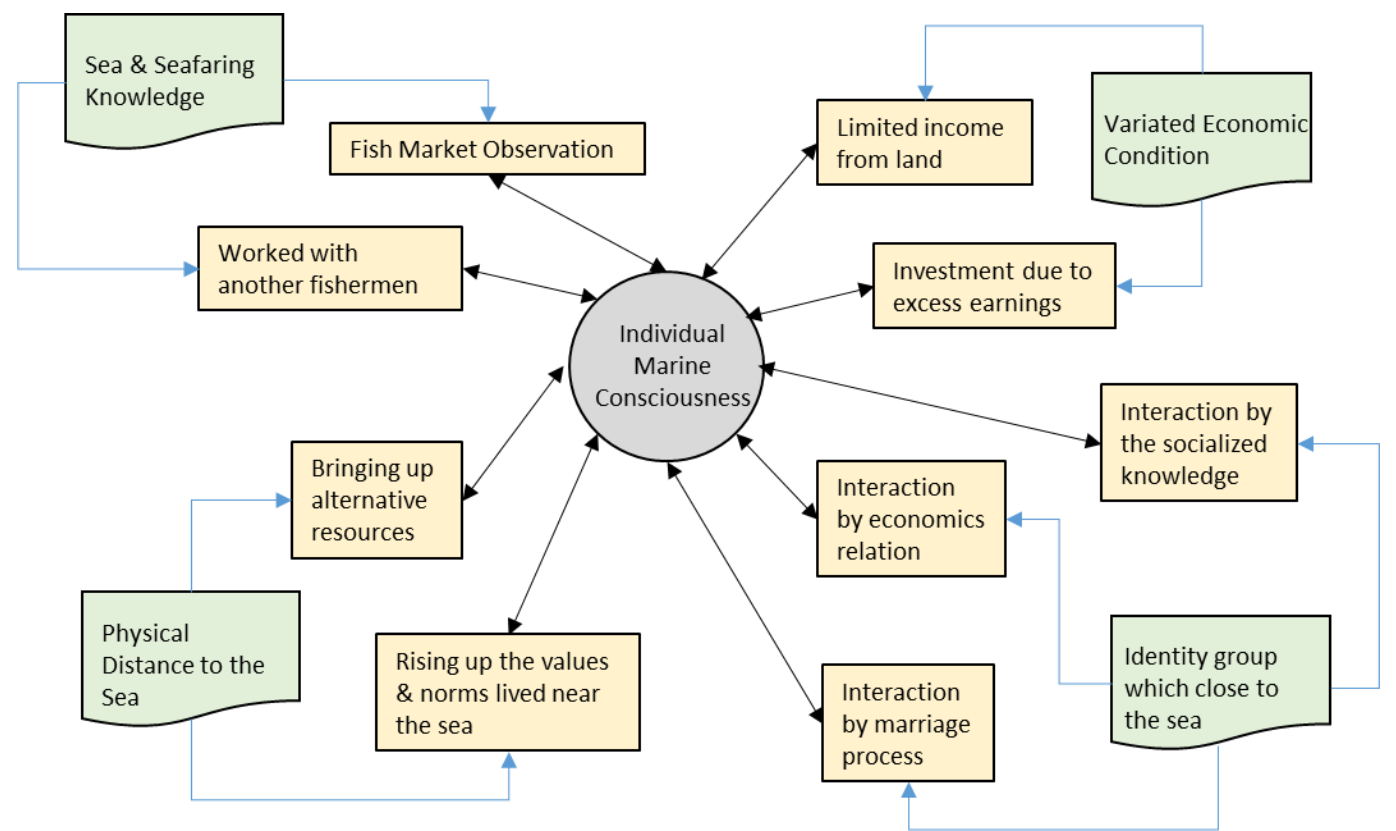

Figure 2. The Sociological Dimension of Seafaring as a Social Practice

The knowledge on the sea and seafaring came from the social interaction between they who have less understanding and those who have complete understanding about the sea and seafaring. The social practice could be in the form of working for a well-experienced group of fishermen or observation at the fish market or fish auction. Meanwhile, as economic condition with the society varies, especially in terms of livelihood from the land, some believe such ways could no longer support their economic needs, pushing people to go to the sea to catch fish. In regards to those who are have better economic condition, however, their approach to the sea could be understood as a form of investing their capital. At this point, the natural distance with the sea provides an alternative source of resources that could be used by the society, which then in turn created consequences of social norms and obligations derived from their daily understanding of the sea. The social practice of seafaring stands on the basic understanding of human interaction with the sea. Base on such argument, the first social class able to access the sea would eventually gain more social position compared to other groups. In this context, the social group is the identity group of Bugis people. In the process, nevertheless, through ongoing and dynamic social process, the knowledge then developed through existing barriers of identity. This was possible through the process of marriage and daily economic relations.

\section{Conclusion}

The degradation of Banten's maritime trade started when the Dutch power entered the region, aimed not only for trading but also to practice its trade monopoly practice in ports. 
The process went along with the degradation of maritime culture of other societies in nusantara. At this point, the orientation of the people of nusantara, including Banten, to the sea decreased and finally degraded. They prefer to develop new agricultural area and forget how once they had a strong connection with the sea. In other words, we could say that the change of the people's cultural orientation from the sea to land, represented by the change of trade orientation from maritime trade to land trade, went along with the weakening of the locals' economic power due to colonialism. The degradation process did not stop when the colonials left and Indonesia became a new country. Present day maritime culture degradation is represented by national until local development systems oriented more on land than the sea, which is clearly an ahistorical perspective of a development system. The arrival of modern land transportation, such as cars, motorcycles and trucks, became a signal that modernization happens on land. In time, thee land transportation vehicles replace sea transportation, including the industry that supports the existence of the later mode. From the area of knowledge and technology, there has been no significant development in the area's shipbuilding industry. It is very different to the land transportation support system, which although does not have its industry in the area, all of its support systems, including repair, spare parts and financial system in regards to the buy-sell process, are much more advanced.

In reality, the social practice of seafaring requires adequate knowledge about the sea and seafaring. Hence, the position of an identity group with deeper understanding about the sea is very crucial. This, however, happened only during the early stages when seafaring knowledge was scarce among the general public. As time pass by, social mechanisms allowing such knowledge to pass through existing identity barriers were formed, eliminating the dominance of one identity group over the other on seafaring knowledge. In process, these social mechanisms created a context of the position of identity groups in terms of disseminating the social practice of seafaring. Post-colonialism, land orientation becomes dominant and eroded existing maritime culture. This reality continues until this very day. That maritime culture is left far behind by land culture is represented today by the various signs of modernization that rarely touches on cultural aspects related to the sea. These modernization signs are represented by how the rapid development of land infrastructure and transportation mode does not occur at sea. This is one of the main reasons why maritime culture degradation continues besides the long historical process.

One of the reasons for maritime culture degradation is how seafaring skills of the people in the area continue to decrease. Knowledge, therefore, becomes very important. Rejuvenation of seafaring knowledge and its development requires the intervention of education-related policies based on the characteristics of local resources, both natural and cultural. This way could promote the revival of seafaring knowledge among the young generation. The development of this knowledge should include the understanding on environmental protection, ecological modernization, seafood processing system, and others. Schools and other educational institution should be placed as medium for students to understand their natural surroundings without having to release themselves from the modernization process happening in their housing areas. Hence, there is a single integration process between social development occurring within societies and state-managed education system. In regards to development, it is crucial to develop adequate infrastructure for the people's access to the sea. It does not suggest that land infrastructure is not important. However, when infrastructure development merely focuses on access for land transportation, it pushes the social and cultural distance between societies and the sea further apart even though their natural distance is very close. Still, the development of sea-related infrastructure should always match the needs of societies around the area, rather than developing infrastructure that are not needed. A more technical suggestion is for the government to promote the development of small docks along the coastal areas with a significant number of fishermen population. Enhancing motor boat technology of fishermen in the area is another suggestion, which will provide an alternative transportation 
choice besides cars and trucks. It is important to also consider ways to develop small-scaled fiber boat/ship industry so that fishermen could utilize this type of vessel in a large number. The government and private sectors could work together in the production of such vessel and sell the products to coastal areas, providing cheaper alternative for boats or ships, both for fishing and for transportation. The selling system may well adopt car or motorcycle purchasing system through credit. Such development should also include after-sale service as well as maintenance and repair facilities.

Since timber would become a scarce commodity in the future, it is crucial to immediately produce fiber ships and boats. Efforts to develop this maritime service industry should be included in existing framework of local capacity development. This could be done by involving parties that have been loyal in the development of knowledge on ship building and repairing. They should become a part of the industry in order to ensure modernization would not push them away and marginalize them. Identity groups that have always been the social symbol of seafaring should also receive adequate attention without causing social jealousy from other groups. Although they are dependable groups in terms of seafaring social practice and maritime culture dissemination, the government should not focus on these groups only. From the perspective of the society's economy, seafaring practice could become the livelihood for those who have limited income from agricultural activities or for those willing to invest their capital to activities at sea. These opportunities should be available to everyone by considering fairness to ensure that prosperity does not belong only to those with large capitals, but also for those who want to increase their limited income. In short, maritime development should always put forward social justice for all members of coastal societies as means to resolve poverty issues.

\section{Acknowledgement}

This research is supported by Indonesia Defense University.

\section{References}

[1] Dirhamsyah, "Analysis of Institutional Arrangements Relevant to Coral Reef Management in Indonesia", Research Centre for Oceanography, Indonesian Institute of Sciences, (2007).

[2] Chief of the Indonesian Navy, "Strategi TNI AL dalam Pengamanan Pulau Terluar di Pulau Dana", Indonesian Navy Strategy in Outermost Island Security in Dana Island, an official paper for a national seminar on state boundaries, organized by Bogor Agricultural University, (2014).

[3] R. Cribb and M. Ford, "Indonesia as An Archipelago: Managing Island, Managing the Seas", Indonesia beyond the Water's Edge, Robert Cribb \& Michele Ford (ed). ISEAS, (2009).

[4] A. Giddens, "The Constitution of Society: Outline of the Theory of Structuration", Polity Press, (1984).

[5] A. Reid, "Asia Tenggara Dalam Kurun Niaga" Jaringan Perdagangan Global Jilid 2, Yayasan Obor, Jakarta, (2011), pp. 1450-1680:

[6] R. P. Dahana, (2011), Intoleran Pada Intoleransi. KOMPAS, (2011).

[7] R. P. Dahana, (2011), Manusia Indonesia Maritim. KOMPAS, (2011).

[8] R. P. Dahana, (2012), Budaya Demokrasi Kita. KOMPAS, (2012).

[9] R. P. Dahana, (2013), Jalesveva Jayamahe. KOMPAS, (2013).

[10] P. S. Worsley, M. F. Supomo, T.H. Hunter, (2014), Kakawin Sumanasantaka: Mati Karena Bunga Sumanasa, Karya Mpu Monaguna. Yayasan Obor Indonesia.

[11] H.D. Evers and S. Darit, "Malaysian Maritime Potential and the Straits of Malacca", Roczniki Socjologii Morskiej, vol. 20, (2011), pp.40-45.

[12] A. Giddens, "Modernity and Self Identity: Self and Society in the Late Modern Age", Stanford University Press, (1991).

[13] P. Bourdieu, "Distinction: A Social Critique of the Judgment of Taste", Richard Nice (translate). Harvard University Press, (1984).

[14] R. Bartlomiejski, "Fisheries Local Action Groups: A New Theme for Researching Maritime Communities", Annuals of Marine Sociology, vol. 20, (2011).

[15] C. Cameron, "Marine Sociology: The Sociology of Marine Agriculture", The American Behavioral Scientist, (pre 1986), Mar 1961.

[16] A.B. Lapian, "Pelayaran dan Perniagaan Nusantara Abad Ke-16 dan 17", Komunitas Bambu, Jakarta, (2008).

[17] S. A. Ebbin, "The Anatomy of Conflict and the Politics of Identity in Two Cooperative Salmon 
Management Regime", Policy Sciences, vol. 37, (2004)

[18] M. Castells, "The Power of Identity", The Information Age: Economy, Society and Culture, vol. 2, 2nd ed. Blackwell Publishing UK, (1997).

[19] A.B. Lapian, "Orang Laut, Bajak Laut, Raja Laut", Sejarah Kawasan Laut Sulawesi Abad XIX. Komunitas Bambu, Jakarta, (2009).

[20] O.W. Wolters, "Kemaharajaan Maritim Sriwijaya di Perniagaan Dunia", Abad III-Abad IV. Komunitas Bambu, (2011).

[21] H.O. Untoro, "Kebesaran dan Tragedi Kota Banten", Yayasan Kota Kita, (2006).

[22] D.A. Lombard, "Nusa Jawa: Silang Budaya III - Warisan Kerajaan Kerajaan Konsentris", Gramedia Pustaka Utama, (2005)

[23] B. Dorleans, "Orang Indonesia dan Orang Prancis", Dari Abad XVI sampai dengan Abad XX, KPG. Jakarta, (2006).

[24] A.R. Hamid, "Sejarah Maritim Indonesia", Penerbit Ombak. Yogyakarta, (2013).

[25] C. Guillot, Banten, Sejarah dan Peradaban Abad X-XVII. KPG-Forum Jakarta Paris-Pusat Penelitian dan Pengembangan Arkeologi Nasional, Jakarta, (2008).

[26] L. Blussé, and J. De Moor, "Nederlanders overzee: de eerste vijftig jaar”, Wever, (1983), pp. 1600-1650. 